\title{
Optimal Tax Policies with Private-Public Clean-Up, Cross-Border Pollution AND CAPITAL MOBILITY
}

\author{
COSTAS HADJIYIANNIS \\ PANOS HATZIPANAYOTOU \\ MICHAEL S. MICHAEL
}

CESIFo WORKING PAPER No. 822

Category 7: Trade Policy

DECEMBER 2002 


\title{
Optimal TAX Policies WITH PRIVATE- PUBLIC ClEAN-UP, CROSS-BORDER POLLUTION AND CAPITAL MOBILITY
}

\begin{abstract}
This paper builds a model of a region with two non-identical countries, cross-border pollution and free movements of goods and capital within the region. Pollution reduces welfare and there is simultaneous private and public pollution abatement. Public pollution abatement is financed with the use of lump-sum and pollution tax revenue. The introduction of public pollution abatement enables us to derive the optimal pollution taxes in terms of the marginal cost of public pollution abatement. We derive and compare for each country the Nash and cooperative lump-sum and pollution taxes and examine how cross-border pollution and capital mobility affect them. Finally, we examine the impact of capital mobility on the effectiveness of pollution taxes on net pollution.
\end{abstract}

JEL Classification: F18, F22, H21.

Keywords: optimal taxes, public pollution abatement, cross-border pollution, capital mobility.

Costas Hadjiyannis

Department of Economis

University of Cyprus

Box 20573

CY 1678, Nicosia

Cyprus

costash@ucy.ac.cy
Panos Hatzipanayotou

Dept of Int. and European

Economic Studies

Athens University of Economics

and Business

76 Patission str. Athens 10434

Greece

hatzip@aueb.gr

Michael S. Michael

Department of Economics

University of Cyprus

P.O. Box 20537

CY 1678, Nicosia

Cyprus

m.s.michael@ucy.ac.cy 


\section{Introduction}

The liberalization of capital markets in the last few decades has raised concerns over the impact of capital mobility on the global environment. Environmentalists claim that some countries in an effort to attract foreign capital lower their environmental standards and become "pollution havens". ${ }^{1}$ This may lead to a "race to the bottom" in environmental standards worldwide. In addition, since the effects of pollution generated in one country are not confined within the geographical borders of that country (i.e. cross-border pollution), this "race to the bottom" may lead to a deterioration of the quality of the environment even in countries with strict environmental standards. ${ }^{2}$ As a result of these and other concerns, a number of international conferences has been staged (e.g., the UN conferences in Rio de Janeiro in 1992 and in Kyoto in 1997, the OECD conference of foreign direct investment and the environment in the Hague in 1999) in order to address these issues. $^{3}$

In light of the above considerations, a literature has emerged studying the impact of capital mobility on the environment. ${ }^{4}$ For example, Merrifield (1988) in a two-country general equilibrium model with international flows of goods, capital and pollution, examines appropriate abatement strategies for reducing cross-border pollution. It is shown, among other things, that an attempt to reduce pollution by means of higher pollution taxes may raise pollution. Copeland (1994) shows that the welfare gains of reforming pollution policy are greater in an economy with capital mobility. Copeland and Taylor (1997) examine the impact of capital mobility on the level of pollution in a two-good (a labor-using "clean" good and a capital-using "dirty" good) North-South model with local pollution. They demonstrate among other things that allowing for free international

\footnotetext{
${ }^{1}$ For example, Gray (1997) using US data finds significant negative correlation between new plant location and inter-state differences in environmental regulation.

${ }^{2}$ Rauscher (1991) notes that, in the absence of cross-border pollution, such competition among countries may not pose a problem from an economic theory point of view, as long as it reflects the countries' preferences. But, with cross-border pollution, matters may actually be different, since a country with tight environmental controls suffers the consequences of such policies (e.g., lower capital endowment) but may not enjoy their benefits (i.e., cleaner environment).

${ }^{3}$ Jaffe, Peterson, Portney, and Stanvis (1995), Grossman and Krueger (1993), Tobey (1990) and Antweiler, Copeland, and Taylor (2001) argue that the empirical evidence does not support the "pollution haven" hypothesis.

${ }^{4}$ Another strand of the literature examines the welfare and policy implications of cross-border pollution e.g., Markusen (1975), Copeland and Taylor (1995), Copeland (1996), Ludema and Wooton (1997), Silva and Caplan (1997) .
} 
capital mobility, world pollution rises (falls) when the North initially exports the dirty (clean) good. Rauscher (1991) and Rauscher (1997) using a model with two countries, one good and cross-border pollution examine the effects of increased capital mobility on the optimal levels of quantitative environmental restrictions (i.e., pollution quotas). It is shown that when the two countries act non-cooperatively, increased capital exports, move capital to the country with less restrictive environmental regulations. Global pollution, however, may be higher or lower relative to the initial situation. ${ }^{5}$

A common analytical assumption in the above studies is that pollution, a by-product of production, is entirely abated by the private sector in response to emission taxes on private producers. ${ }^{6}$ More often than not, however, pollution emissions are abated partly by the private and partly by the public sector of a country. Ample empirical evidence shows that the share of public abatement expenditure in total abatement expenditure is sizeable and it varies among countries and from one type of pollution to another. ${ }^{7}$ Thus, it is important that both types of abatement are taken into consideration in analyzing environmental policies, especially in light of the fact that emission tax revenue is often earmarked for pollution abatement activities by governments. ${ }^{8}$ To the best of our knowledge, with the exception of Hatzipanayotou, Lahiri, and Michael (2002a), the literature has ignored this issue. They consider the issue of simultaneous provision of private and public abatement, where the latter activity is financed through emission tax revenue but in a different framework. ${ }^{9}$

The present paper develops a general model incorporating simultaneous public and private pollution abatement to study the interaction between capital mobility and the

\footnotetext{
${ }^{5}$ In a different context Chao and $\mathrm{Yu}(1998)$ and Chao and $\mathrm{Yu}(2000)$ raise other issues regarding the interaction between international capital mobility and locally abated pollution.

${ }^{6}$ Markusen, Morey, and Olewiler (1993) report a number of examples of pollution taxes. Those include a 1988 tax on fuels in the Netherlands, a 1990 French air pollution tax and a 1990 US tax on the ozone-depleting factor of a variety of chlorofluorocarbons.

${ }^{7}$ According to OECD statistics, as far as abatement of water pollution in the early 1990s is concerned, the share of public expenditure in the total expenditure is $66 \%$ in the USA and the Netherlands and only $12 \%$ in the UK. As for abatement of air pollution, the share of public abatement in the Netherlands and the UK is $55 \%$ and $30 \%$ respectively, but it is only $6 \%$ in the case of the USA.

${ }^{8}$ For example, Brett and Keen (2000) note that, in the US, it is quite customary for environmental taxes to be earmarked for specific environment related public expenditure. In particular, such tax proceeds are commonly paid into trust funds that finance various clean-up activities, or are spend on road and public transport networks.

${ }^{9} \mathrm{Chao}$ and $\mathrm{Yu}(1999)$ also use public pollution abatement in their model and examine its effect on welfare when it is financed through foreign aid.
} 
environment. To this end, we construct a general equilibrium model of a region with two non-identical countries and free commodity and capital flows. We assume that pollution, a by-product of production, generated in each country is transmitted across borders, and it is abated partly by the private producers, in response to an emissions tax, and partly by the local governments. Governments finance their public pollution abatement activities using lump-sum and pollution tax revenue. Within this framework, we first examine the effect of pollution taxes on public pollution abatement activity and on net pollution and compare the results with the existing literature. We then derive the cooperative and Nash optimal pollution taxes and relate them to the marginal cost of public pollution abatement. We also analyze how public pollution abatement, capital mobility and differences between the two countries affect these taxes. Finally, we extend the analysis to examine the impact of capital mobility on the effectiveness of the environmental policy.

\section{The Analytical Framework}

\subsection{The Model}

We develop a general equilibrium model of two small open economies, home and foreign, which trade freely with each other and the rest of the world. ${ }^{10}$ As a result, commodity prices in the two countries are constant and equal to the world commodity prices. In both countries pollution of the eyesore type is generated as a by-product of production, and it is transmitted across national borders. Identical residents, inhabiting each country, are adversely affected and suffer disutility from locally generated pollution and from pollution emitted by foreign producers and transmitted across borders. With respect to the flows of factors of production, it is assumed that capital is freely mobile within the borders of the region, but immobile between the region and the rest of the world. Finally, other factors of production, such as labor, are intra-regionally and internationally immobile. ${ }^{11}$

We proceed to develop the model of the home, capital-importing, country; the model of the foreign, capital-exporting, country follows analogously. The home country's maxi-

\footnotetext{
${ }^{10}$ Following the standard convention we denote all the variables of the foreign country with an asterisk.

${ }^{11}$ We conjecture that the model may resemble the case of a region -either with all its members developed (e.g., EU) or some developed and some developing (e.g., NAFTA)- vis-à-vis the rest of the world. In such a context, there is free commodity trade within the region, and nearly free commodity trade between the region and the rest of the world.
} 
mum value of production of private goods is denoted by the revenue function, $R(p, v, t, K)$, defined as:

$$
R(p, v, t, K)=\max _{x, z, K}\left\{p^{\prime} x-t z:(x, z, K) \in \Phi(v, K)\right\},
$$

where $p$ is the vector of exogenously given world commodity prices, $\Phi(v, K)$ is the country's aggregate technology set, $v$ is the endowment vector of the immobile factors, $K$ is the domestic supply of capital, $x$ is the vector of net outputs, and $z$ is the amount of pollution emission by the private sector, net of the amount abated by the private sector. ${ }^{12}$ In the present analysis, since $(v)$ and $(p)$ are invariant, for notational simplification the revenue function is written as $R(t, K)$. We assume that the $R(t, K)$ function is strictly concave in $K\left(R_{K K}<0\right)$ and strictly convex in $t\left(R_{t t}>0\right)$. The latter assumption implies that a higher emission tax level lowers the amount of pollution emissions by the private sector. By the envelop theorem, the partial derivative of the revenue function with respect to $K$, (i.e., $R_{K}$ ) is the marginal revenue product of capital, and by the same theorem, the level of pollution, $z$, generated by the private sector is given by ${ }^{13}$

$$
z=-R_{t}(t, K)
$$

For the rest of the analysis we assume that pollution is capital intensive in both countries, that is, $R_{t K}<0$ and $R_{t^{*} K^{*}}^{*}<0$.

Accounting for both private and public sector pollution abatement, the overall net pollution $r$, affecting the home country residents is:

$$
r=z-g+\Theta\left(z^{*}-g^{*}\right)
$$

where the parameter $\Theta \in[0,1]$ is the rate of cross-border pollution or the spillover parameter, $g$ is the level of public pollution abatement in the home country, and $z^{*}$ and $g^{*}$ denote the levels of pollution net of private abatement and the level of public pollution abatement, respectively, in the foreign country. ${ }^{14}$

\footnotetext{
${ }^{12}$ For simplicity we assume only one type of pollution emission generated in one or more sectors. A prime $\left({ }^{\prime}\right)$ denotes a transposed vector or matrix, and $p^{\prime} x-t z$ is the value of factor income. Finally, $\Phi(v, K)$ includes production technologies and abatement technologies in various private sectors, as they carry out some pollution abatement in response to the emission tax $(t)$.

${ }^{13}$ Copeland (1994) and Turunen-Red and Woodland (1998), among others, define pollution in the same way.

${ }^{14}$ This formulation of additive level of net pollution, $r$, implies that the two countries emit the same
} 
As for the country's public sector, we assume that it imports from the rest of the world, at a constant price $P_{g}$, a commodity used to provide public pollution abatement at the level $g$. The cost of the imported good $\left(i . e ., P_{g} g\right.$ ), used for public pollution abatement, is financed through the emission tax revenue (i.e., $-t R_{t}(t, K)$ ), and lump-sum taxes $(T)$. Thus, the government's budget constraint is written as:

$$
P_{g} g=-t R_{t}(t, K)+T
$$

Turning to the demand side of the economy, we assume that each country is comprised of identical individuals. Utility is adversely affected by both local and foreign pollution transmitted across borders. Let $E(u, r)$ denote the minimum expenditure required to achieve a level of utility, $u$, at constant prices $p$, omitted from the expenditure function for reasons noted earlier, and at the given level of net pollution $r$. The partial derivative of the expenditure function with respect to $u, E_{u}$, denotes the reciprocal of the marginal utility of income. Since pollution adversely affects household utility, the partial derivative of the expenditure function with respect to $r, E_{r}$, is positive denoting the households' marginal willingness to pay for a reduction in pollution (e.g. see Chao and Yu (1999)). ${ }^{15}$ That is, a higher level of net pollution requires a higher level of spending on private goods to mitigate its detrimental effects so that a constant level of utility is maintained. The expenditure function is assumed strictly convex in $r$, i.e. $E_{r r}>0$. That is, a higher level of net pollution raises the households' marginal willingness to pay for its reduction. It is also assumed that $E_{r u}>0$, i.e. a higher level of utility increases the households' marginal willingness to pay for pollution abatement. ${ }^{16}$

The home, capital-importing, country's budget constraint requires that private spending $E(u, r)$ must equal factor income from the production of goods $R(t, K)$ minus repatriated earnings of foreign capital domestically employed $k^{f} R_{K}(t, K)$ and lump-sum taxes $T$. Thus, the income-expenditure identity for the home country is

$$
E(u, r)=R(t, K)-k^{f} R_{K}(t, K)-T
$$

pollutant. Generalizing the present specification to one where the two countries emit different types of pollutants only results to unwarranted algebraic complications without providing substantive analytical insight.

${ }^{15}$ In Copeland (1994)'s terminology, $E_{r}$ is a measure of the marginal damage to consumers from pollution.

${ }^{16}$ This implicitly assumes that pollution abatement is a normal good. 
where $k^{f}$ is the amount of foreign capital operating in the home country.

The model for the foreign country is similarly developed. The corresponding equations for the foreign country are

$$
\begin{aligned}
z^{*} & =-R_{t^{*}}^{*}\left(t^{*}, K^{*}\right) \\
r^{*} & =z^{*}-g^{*}+\Theta^{*}(z-g) \\
P_{g^{*}}^{*} g^{*} & =-t^{*} R_{t^{*}}^{*}\left(t^{*}, K^{*}\right)+T^{*} \\
E^{*}\left(u^{*}, r^{*}\right) & =R^{*}\left(t^{*}, K^{*}\right)+k^{f} R_{K}(t, K)-T^{*},
\end{aligned}
$$

where $r^{*}$ is the level of total net pollution for the foreign country, $\Theta^{*}$ is the rate of crossborder pollution in that country and $K^{*}$ is the supply of capital. By the assumptions of the model $d K=d k^{f}=-d K^{*}$.

Finally, international capital mobility though non-existent between the region and the rest of the world, is perfect within the region, i.e., between the home and foreign countries. Since it is assumed that capital earnings are untaxed by both countries, perfect regional capital mobility equalizes the factor's reward in the two countries. That is, equilibrium in the region's capital market requires that

$$
R_{K}(t, K)=R_{K^{*}}^{*}\left(t^{*}, K^{*}\right)
$$

The system of equations (2)-(10) contains nine unknowns, namely $u, u^{*}, g, g^{*}, z, z^{*}$, $r, r^{*}$ and $K$; four -two for each country- policy parameters, namely $(t, T)$ and $\left(t^{*}, T^{*}\right)$; and four -two for each country- exogenous parameters, namely $\left(P_{g}, \Theta\right)$ and $\left(P_{g^{*}}^{*}, \Theta^{*}\right)$. For analytical convenience the above system is reduced to equations (4), (5), (8), (9) and (10), after appropriately substituting equations (2) and (3) into equation (5), and equations (6) and (7) into equation (9). In doing so the initial system is then solved in terms of five unknowns, namely $u, u^{*}, g, g^{*}$, and $K$. The Appendix of the paper lays out the complete comparative statics of this reduced form system.

\subsection{Pollution Taxes and Public Pollution Abatement}

This section analyzes an issue not explicitly examined by the relevant literature. It examines the effect of an increase in pollution taxes on domestic and foreign public pollution abatement and how it is affected by capital mobility. From the Appendix it is 
easily derived that a higher pollution tax causes a capital outflow from the home country (i.e., $\left.(d K / d t)=\frac{-R_{t K}}{H}<0\right)$, and thus a capital inflow to the foreign country. The effect of the higher $(t)$ on domestic public sector pollution abatement activity is given by

$$
\frac{d g}{d t}=\left(\frac{\partial g}{\partial t}\right)-\frac{t R_{t K}}{P_{g}}\left(\frac{d K}{d t}\right)=-\frac{R_{t}}{P_{g}}-t\left(\frac{R_{t t}}{P_{g}}-\frac{R_{t K}^{2}}{H P_{g}}\right)
$$

where $H=R_{K^{*} K^{*}}^{*}+R_{K K}$ and is negative.

Equation (11) indicates that the effect of a higher $(t)$ on $(g)$ is through its effect on home country government revenue. In particular, the higher $(t)$ entails a direct positive effect on government revenue (i.e., $-R_{t} / P_{g}$ ), which enhances the public sector's ability to provide $(g)$, and an indirect negative effect (i.e., $-t\left(R_{t t} / P_{g}-R_{t K}^{2} / H P_{g}\right)$ ) which mitigates its ability for the provision of $(g)$. Intuitively the direct positive effect indicates that at a given level of pollution $\left(-R_{t}\right)$ a higher $(t)$ raises government revenue, and thus the level of $(g)$ provided by the public sector. On the other hand, the higher $(t)$ reduces government pollution tax revenue in two ways. First, pollution falls directly as a result of the higher $(t)$ (i.e., $-t R_{t t} / P_{g}<0$ ). Second, it causes a reduction in $R_{K}$ which in turn causes a capital outflow and thus a reduction in pollution (i.e., $-t R_{t K}^{2} / H P_{g}$ ). In the absence of capital mobility this last effect does not exist. Therefore, the existence of capital mobility decreases the ability of the increase in pollution taxes to increase public pollution abatement. For a small $(t)$ (i.e. $t \simeq 0$ ) an increase in its level unambiguously raises government pollution tax revenue and, thus the provision of $(g)$, through the induced direct positive effect.

The effect of the higher $(t)$ on foreign public sector pollution abatement activity is given by

$$
\frac{d g^{*}}{d t}=-\frac{t^{* R_{t^{*} K^{*}}^{*}}}{P_{g^{*}}^{*}} \frac{R_{t K}}{H} .
$$

Equation (12) indicates that a higher pollution tax level by the home country raises public sector pollution abatement in the foreign country. Intuitively, a higher $(t)$ lowers $R_{K}$, induces an inflow of capital in the foreign country, which in turn raises the level of foreign pollution. That results in higher pollution tax revenue in the foreign country, thus enhancing the public sector's ability to provide public pollution abatement. Note that in the absence of capital mobility a change in $t$ does not affect $g^{*}$. 


\section{Taxes, Pollution and Welfare}

In this section we examine the effect of a higher domestic pollution tax $(t)$ on net pollution in the two countries, $(r)$ and $\left(r^{*}\right)$ and on levels of national welfare $(u)$ and $\left(u^{*}\right)$. Analogous results are stated for the effects of a higher tax $\left(t^{*}\right)$ on the aforementioned variables. We also examine the effects of higher lump-sum taxes, $T$ and $T^{*}$ for each country respectively, on the corresponding level of national welfare. The effect of environmental policy on pollution in the presence of capital mobility are examined in other studies as well (e.g. Rauscher (1991), Copeland and Taylor (1997)).

\subsection{Pollution Taxes and Net Pollution}

The effect of a higher pollution $(t)$ on domestic net pollution $(r)$ can be derived as follows. Using equations (3), (11), (12) and the Appendix we have

$$
\begin{aligned}
\frac{d r}{d t}= & -\left(\frac{d g}{d t}+\Theta \frac{d g^{*}}{d t}\right)-\left[R_{t t}+\left(R_{t K}-\Theta R_{t^{*} K^{*}}^{*}\right) \frac{d K}{d t}\right] \\
= & -\Delta^{-1} P_{g^{*}}^{*}\left(H R_{t t}-R_{t K}^{2}\right)\left(P_{g}-t\right)- \\
& \Delta^{-1} \Theta P_{g} R_{t K} R_{t^{*} K^{*}}^{*}\left(P_{g^{*}}^{*}-t^{*}\right)+\Delta^{-1} H P_{g^{*}}^{*} R_{t}
\end{aligned}
$$

where $\Delta=H P_{g} P_{g^{*}}^{*}$ and is negative. Intuitively, equation (13) shows that a higher $\operatorname{tax}(t)$ affects domestic net pollution $(r)$, first through its impact on public abatement in the home and foreign countries. This effect is ignored by the literature that does not account for public pollution abatement. Second, it affects $(r)$ through changes in domestic and foreign levels of pollution. In particular, changes in domestic pollution $(z)$ are due to changes in the domestic pollution tax (direct effect) and changes in the domestic capital stock (indirect effect). Both effects lead to a reduction of $(z)$. On the other hand, the higher $(t)$ affects foreign pollution $\left(z^{*}\right)$ indirectly through changes in the foreign country's capital stock $\left(K^{*}\right)$. This effect increases $\left(z^{*}\right)$ and through cross-border pollution it increases $(r) .{ }^{17}$

Equivalently, the effect of the higher pollution tax $(t)$ on net foreign pollution $\left(r^{*}\right)$ is shown to be

\footnotetext{
${ }^{17}$ Hatzipanayotou, Lahiri, and Michael (2002a) ignore these last two effects on pollution because they examine this issue in a model with $\Theta=0$ and no capital mobility.
} 


$$
\begin{aligned}
\frac{d r^{*}}{d t}= & -\left(\frac{d g^{*}}{d t}+\Theta^{*} \frac{d g}{d t}\right)-\left[\Theta^{*} R_{t t}+\left(\Theta^{*} R_{t K}-R_{t^{*} K^{*}}^{*}\right) \frac{d K}{d t}\right] \\
= & -\Delta^{-1} \Theta^{*} P_{g^{*}}^{*}\left(H R_{t t}-R_{t K}^{2}\right)\left(P_{g}-t\right)- \\
& \Delta^{-1} P_{g} R_{t K} R_{t^{*} K^{*}}^{*}\left(P_{g^{*}}^{*}-t^{*}\right)+\Delta^{-1} \Theta^{*} H P_{g^{*}}^{*} R_{t} .
\end{aligned}
$$

Observing the reduced forms of equations (13) and (14) we state sufficient conditions under which an increase in $(t)$ reduces net pollution $(r)$ in the home country and $\left(r^{*}\right)$ in the foreign country, in the following Proposition.

Proposition 1 Consider a two-country region where there is perfect regional capital mobility and cross-border pollution, and where pollution tax revenue in each country is earmarked for the provision of a public pollution abatement. Then, a sufficient condition for an increase in $(t)$ to reduce $(r)$ and $\left(r^{*}\right)$ is that $\left(P_{g}>t\right)$ in the home country and $\left(P_{g^{*}}^{*}<t^{*}\right)$ in the foreign country.

It is worth noting that in the absence of cross-border pollution, i.e., $\Theta=\Theta^{*}=0$, we get the following results:

1. $(d r / d t)<0$ if $\left(P_{g}>t\right)$ and $\left(d r^{*} / d t\right)<0$ if $\left(P_{g^{*}}^{*}<t^{*}\right)$, and

2. changes in one country's pollution tax affects the other country's net pollution through the induced regional capital mobility.

In the absence of public sector pollution abatement and of cross-border pollution in both countries, i.e., $\Theta=\Theta^{*}=0$, we unambiguously obtain that $d r / d t<0$ and $d r^{*} / d t>0$. In the absence of public sector abatement but in the presence of cross-border pollution, i.e. $\Theta>0$ and $\Theta^{*}>0, d r / d t<0$ and $d r^{*} / d t<0$ if $R_{t K}=R_{t^{*} K^{*}}^{*}$. Analogous results are inferred for an increase in the foreign country's pollution tax $\left(t^{*}\right)$ on the home and foreign countries' levels of net pollution.

\subsection{Lump-sum Taxes, Pollution Taxes and Welfare}

In this section, we examine the welfare effects of small changes in policy variables and we show how the existence of public pollution abatement and capital mobility alter the 
existing results. Differentiating equation (5) gives

$$
\begin{aligned}
d u & =E_{r} d g+\Theta E_{r} d g^{*}-\left[-E_{r}\left(R_{t K}-\Theta R_{t^{*} K^{*}}^{*}\right)+k^{f} R_{K K}\right] d K \\
& +\left[E_{r} R_{t t}+R_{t}-k^{f} R_{K t}\right] d t+\Theta E_{r} R_{t^{*} t^{*}}^{*} d t^{*}-d T
\end{aligned}
$$

where for simplicity we set $E_{u}=1$. The first two terms on the right hand side of equation (15) show that, other things being equal, a higher level of public pollution abatement at home or abroad increases welfare. The coefficient of $d K$ shows that the inflow of capital in the home country affects domestic welfare in two ways. First, it affects welfare positively through lower payments to foreign capital operating at home (i.e., $-k^{f} R_{K K}>0$ ), and second, it affects welfare through induced changes in the levels of pollution at home and abroad (i.e., $\left.E_{r}\left(R_{t K}-\Theta R_{t^{*} K^{*}}^{*}\right)\right)$. In the absence of cross-border pollution (i.e., $\Theta=0$ ) the inflow of capital has a negative impact on welfare through this term, but still an ambiguous one overall. On the other hand, if $\Theta>0$, then the regional capital mobility, which reduces $K^{*}$ and lowers cross-border pollution, exerts a positive impact on welfare through the term $-E_{r} \Theta R_{t^{*} K^{*}}^{*}$.

A higher local environmental tax $(t)$ exerts a positive impact on domestic welfare through a lower level of domestic pollution (i.e., $E_{r} R_{t t}>0$ ), and through a lower rate of return on capital, and thus payments to foreign capital operating domestically (i.e., $-k^{f} R_{K t}>$ $0)$. But, a higher level of $(t)$ also exerts a negative impact on welfare since it entails the allocation of more resources to private abatement, thus the reduction of private incomes and welfare (i.e., $R_{t}<0$ ). Finally, a higher level of the foreign environmental tax $\left(t^{*}\right)$, in the presence of cross-border pollution, or a lower level of domestic lump-sum taxes $(T)$, ceteris paribus, unambiguously raise home welfare. Analogous results can be derived for the foreign country by totally differentiating equation (9).

Now we turn our attention to the effects of lump-sum taxes and pollution taxes on national welfare in the two countries. In particular, using the Appendix, the effect of an increase in the domestic (foreign) lump-sum taxes on domestic (foreign) welfare is given by

$$
\begin{gathered}
\frac{d u}{d T}=\frac{S_{g}}{P_{g}} \\
\frac{d u^{*}}{d T^{*}}=\frac{S_{g^{*}}^{*}}{P_{g^{*}}^{*}},
\end{gathered}
$$


where $S_{g} \equiv\left(E_{r}-P_{g}\right)$ and $S_{g^{*}}^{*} \equiv\left(E_{r^{*}}^{*}-P_{g^{*}}^{*}\right)$. We say that the public pollution abatement is locally under(over)-provided in the home country if $S_{g}>0(<0)$, and in the foreign country if $S_{g^{*}}^{*}>0(<0)$. Therefore, raising lump-sum taxes is unambiguously welfare improving (deteriorating) if the public pollution abatement is locally under (over)-provided. Public pollution abatement is locally optimally provided in the home (foreign) country if $S_{g}=0\left(S_{g^{*}}^{*}=0\right)^{j}$. That is, if $E_{r}=P_{g}\left(E_{r^{*}}^{*}=P_{g^{*}}^{*}\right)$. This is the Samuelson rule for optimal public good provision within each country. In this context public pollution abatement is a public good.

Using the Appendix and equations (15) and (13), the welfare effect of an increase in home country's pollution tax $(t)$ on its own welfare is given by

$$
\begin{aligned}
\frac{d u}{d t} & =R_{t}-E_{r} \frac{d r}{d t}-k^{f}\left(R_{K t}+R_{K K} \frac{d K}{d t}\right) \\
& =\Delta^{-1} E_{r} P_{g^{*}}^{*}\left(H R_{t t}-R_{t K}^{2}\right)\left(P_{g}-t\right)+\Delta^{-1} \Theta R_{t K} R_{t^{*} K^{*}}^{*} P_{g} E_{r}\left(P_{g^{*}}^{*}-t^{*}\right) \\
& +\Delta^{-1} H P_{g^{*}}^{*} R_{t}\left(P_{g}-E_{r}\right)-\Delta^{-1} k^{f} R_{t K} R_{K^{*} K^{*}}^{*} P_{g} P_{g^{*}}^{*}
\end{aligned}
$$

Equation (18) shows that the increase in $(t)$ affects the home country's level of welfare in three ways. The higher $(t)$ induces, first, a transfer of additional resources from production of goods to pollution abatement by private producers. As a result real income, and, therefore, welfare is reduced (i.e., $\left.R_{t}<0\right)$. Second, it affects $(u)$ through changes in domestic net pollution (i.e., $-E_{r} \frac{d r}{d t}$ ). Namely, since $E_{r}$ is the households' marginal willingness to pay for pollution abatement, then $-E_{r} \frac{d r}{d t}$ is a measure of the marginal benefit/damage of changes in $(r)$ due to the increase in $(t)$ on households' utility. Through this term, the increase in $(t)$ increases $(u)$ if $\frac{d r}{d t}<0$ (see sufficient conditions for this result in Proposition (1)). Third, the term $-k^{f}\left(R_{K t}+R_{K K} \frac{d K}{d t}\right)$ captures the effect of $(t)$ on $(u)$ through changes in payments to foreign capital operating at home. This change in payments to $k^{f}$ is due to changes in the domestic marginal revenue product of capital, $R_{K}$, induced by the higher $(t)$. Namely, by assumption, a higher $(t)$ reduces $R_{K}$ and thus payments to $k^{f}$. In addition, as previously discussed, $\frac{d K}{d t}<0$ causing an increase in the marginal revenue product of capital and thus an increase in payments to $k^{f}$. It can be shown, however, that the positive direct effect $\left(-k^{f} R_{K t}\right)$ always dominates the negative indirect effect $\left(-k^{f} R_{K K} \frac{d K}{d t}\right)$. Thus, the overall impact of $(t)$ on $(u)$ through changes in payments to $k^{f}$ is positive, as shown by the last term, (i.e., $-\Delta^{-1} k^{f} R_{t K} R_{K^{*} K^{*}}^{*} P_{g} P_{g^{*}}^{*}$ ), of the reduced form of equation (18). 
Public pollution abatement affects $(d u / d t)$ through its effect on $(d r / d t)$. As shown in Section 3.1 the effect of public pollution abatement on $(d r / d t)$ is ambiguous. Therefore, its effect on welfare is also ambiguous but of the opposite sign. In the absence of capital mobility a small increase in pollution taxes, increases $g$ (equation (11)), decreases $r$ (equation (13)), and increases $u$ (equation (18)).

The effect of an increase in $(t)$ on the foreign country's level of welfare is given by

$$
\begin{aligned}
\frac{d u^{*}}{d t}= & -E_{r^{*}}^{*} \frac{d r^{*}}{d t}+k^{f}\left(R_{K t}+R_{K K} \frac{d K}{d t}\right) \\
= & \Delta^{-1} \Theta^{*} E_{r^{*}}^{*} P_{g^{*}}^{*}\left(H R_{t t}-R_{t K}^{2}\right)\left(P_{g}-t\right)-\Delta^{-1} H P_{g^{*}}^{*} \Theta^{*} E_{r^{*}}^{*} R_{t} \\
& +\Delta^{-1} E_{r^{*}}^{*} P_{g} R_{t^{*} K^{*}}^{*} R_{t K}\left(P_{g^{*}}^{*}-t^{*}\right)+\Delta^{-1} k^{f} R_{K^{*} K^{*}}^{*} R_{t K} P_{g} P_{g^{*}}^{*}
\end{aligned}
$$

Equation (19) shows that an increase in $(t)$ affects $\left(u^{*}\right)$, through, first, its effect on net pollution, $\left(r^{*}\right)$, and second through its effect on repatriated payments of its capital operating in the home country. The discussion of the first effect follows the discussion of equation (14), and the discussion of the second one follows that of equation (18). Just as above, public pollution abatement affects $\left(d u^{*} / d t\right)$ through its effect on $\left(d r^{*} / d t\right)$. From the discussion in Section 3.1 this effect is ambiguous and therefore its effect on $\left(d u^{*} / d t\right)$ is also ambiguous but of the opposite sign.

Analogously, using the Appendix, the reduced form expressions of an increase in $\left(t^{*}\right)$ on welfare in the foreign country $\left(u^{*}\right)$ and in the home country $(u)$ are given by the following equations

$$
\begin{aligned}
& \Delta \frac{d u^{*}}{d t^{*}}=E_{r^{*}}^{*} P_{g}\left(H R_{t^{*} t^{*}}^{*}-R_{t^{*} K^{*}}^{* 2}\right)\left(P_{g^{*}}^{*}-t^{*}\right)+\Theta^{*} R_{t K} R_{t^{*} K^{*}}^{*} P_{g^{*}}^{*} E_{r^{*}}^{*}\left(P_{g}-t\right) \\
& +H P_{g} R_{t^{*}}^{*}\left(P_{g^{*}}^{*}-E_{r^{*}}^{*}\right)+k^{f} R_{t^{*} K^{*}}^{*} R_{K K} P_{g} P_{g^{*}}^{*} \text {, and } \\
& \Delta \frac{d u}{d t^{*}}=\Theta E_{r} P_{g}\left(H R_{t^{*} t^{*}}^{*}-R_{t^{*} K^{*}}^{* 2}\right)\left(P_{g^{*}}^{*}-t^{*}\right)-H P_{g} \Theta E_{r} R_{t^{*}}^{*} \\
& +E_{r} P_{g^{*}}^{*} R_{t^{*} K^{*}}^{*} R_{t K}\left(P_{g}-t\right)-k^{f} R_{K K} R_{t^{*} K^{*}}^{*} P_{g} P_{g^{*}}^{*}
\end{aligned}
$$

The discussion of equations (20) and of (21) is analogous to that of equations (18) and of (19). 


\section{Optimal Lump-sum and Pollution Taxes}

In this section we derive and discuss the properties of the optimal pollution taxes, $(t)$ and $\left(t^{*}\right)$, and lump-sum taxes, $T$ and $T^{*}$, in the two countries, under two alternative cases depending on whether or not there exists tax policy cooperation between the two countries. One of the advantages of including public pollution abatement into the model is that equilibrium pollution taxes are given as a function of the cost of providing pollution abatement.

\subsection{Cooperative Taxes and Welfare}

A standard result in the literature of environmental economics is that in the presence of cross-border pollution externalities optimal policy requires either the adoption of cooperative policies among regions or the mandate of policies by a central (e.g., federal) authority. ${ }^{18}$ Here, we begin our analysis of tax policy choices by presenting the first-best policy choices of the region. This regime entails the simultaneous cooperative choice of lump-sum and pollution taxes that maximize the two countries' joint welfare. This regime constitutes a benchmark solution to which the Nash equilibrium results to follow are compared. Even though for the purposes of our analysis this case is used only as a benchmark, in a region with deep economic integration (e.g., the EU), this may be a plausible equilibrium.

\subsubsection{Cooperative Lump-sum Taxes and Welfare}

The maximization of the countries' joint welfare requires setting $\frac{d u}{d T}+\frac{d u^{*}}{d T}=0$ and $\frac{d u}{d T^{*}}+\frac{d u^{*}}{d T^{*}}=0$, where $\frac{d u}{d T}$ and $\frac{d u^{*}}{d T^{*}}$ are given by equations (16) and (17), respectively. Moreover, using the Appendix we get

$$
\frac{d u}{d T^{*}}=\frac{\Theta E_{r}}{P_{g^{*}}^{*}} \text { and }
$$

\footnotetext{
${ }^{18}$ Hoel and Shapiro (2001) in a multi-regional multi-emissions model of transboundary pollution demonstrates that with free and costless population mobility amongst them, the efficient policy (e.g., regional contribution to environmental degradation, local pollution taxes, and inter-regional transfers) outcome is a Nash equilibrium game among the regions. Since, however, multiple Nash equilibria are likely, policy coordination among the regions may still be necessary in order to achieve the best equilibrium.
} 


$$
\frac{d u^{*}}{d T}=\frac{\Theta^{*} E_{r^{*}}^{*}}{P_{g}} .
$$

From equations (16), (17), (22) and (23) we get that the cooperative first-best policy choice for provision of public abatement requires that

$$
\begin{gathered}
\bar{E}_{r} \equiv\left(E_{r}+\Theta^{*} E_{r^{*}}^{*}\right)=P_{g} \text { and } \\
\bar{E}_{r^{*}}^{*} \equiv\left(E_{r^{*}}^{*}+\Theta E_{r}\right)=P_{g^{*}}^{*} .
\end{gathered}
$$

Intuitively, a unit of pollution generated at home causes $E_{r}$ damage in the home country and $\Theta^{*} E_{r^{*}}^{*}$ damage in the foreign country. Thus $\bar{E}_{r} \equiv\left(E_{r}+\Theta^{*} E_{r^{*}}^{*}\right)$ is the global damage caused by a unit of locally generated pollution. Similarly $\bar{E}_{r^{*}}^{*} \equiv\left(E_{r^{*}}^{*}+\Theta E_{r}\right)$ is the global damage caused by a unit of foreign generated pollution. Therefore, $\bar{E}_{r}\left(\bar{E}_{r}^{*}\right)$ is the global marginal willingness to pay for pollution abatement of the domestically (foreign) generated pollution. When $\bar{E}_{r}-P_{g}>0(<0)$ we say that the public pollution abatement in the home country is globally under-provided (over-provided), and when $\bar{E}_{r}=P_{g}$, the public pollution abatement in the home country is globally optimally provided. Similar definitions apply for the foreign country.

Equations (24) and (25) indicate that maximizing joint welfare requires that lumpsum taxes in each country are set at a level where the global marginal willingness to pay for pollution abatement for pollution generated in each country equals the unit cost of providing it (i.e., $\bar{E}_{r}=P_{g}$ and $\bar{E}_{r^{*}}^{*}=P_{g^{*}}^{*}$ ). Note that these two equations represent the relevant Samuelson rule for optimal provision of public (pollution abatement) goods. Moreover, because of the existence of cross-border pollution, the relevant Samuelson rule accounts not only for the marginal willingness to pay for pollution abatement within a country, but also for the marginal willingness to pay for it in the other country.

\subsubsection{Cooperative Pollution Taxes and Welfare}

Deriving the cooperative first-best choice of pollution taxes requires setting $\frac{d u}{d t}+\frac{d u^{*}}{d t}=0$ and $\frac{d u}{d t^{*}}+\frac{d u^{*}}{d t^{*}}=0$, where $\frac{d u}{d t}$, and $\frac{d u^{*}}{d t}$ are given by equations (18) and (19), respectively. Moreover, the reduced form equations for the expressions $\frac{d u^{*}}{d t^{*}}$ and $\frac{d u}{d t^{*}}$ are given by equations (20) and (21). In general, the cooperative pollution taxes for the two countries are 
given by

$$
\begin{gathered}
t^{c}=P_{g}-\frac{H P_{g} \bar{E}_{r}^{*}\left[\left(H R_{t^{*} t^{*}}^{*}-R_{t^{*} K^{*}}^{* 2}\right) P_{g^{*}}^{*} R_{t} \hat{S}_{g}-R_{t^{*}}^{*} R_{t K} R_{t^{*} K^{*}}^{*} P_{g} \hat{S}_{g^{*}}^{*}\right]}{\bar{E}_{r} \bar{E}_{r^{*}}^{*} P_{g} P_{g^{*}}^{*}\left[\left(H R_{t t}-R_{t K}^{2}\right)\left(H R_{t^{*} t^{*}}^{*}-R_{t^{*} K^{*}}^{* 2}\right)-R_{t K}^{2} R_{t^{*} K^{*}}^{* 2}\right]} \\
t^{* c}=P_{g^{*}}^{*}-\frac{H P_{g^{*}}^{*} \bar{E}_{r}\left[\left(H R_{t t}-R_{t K}^{2}\right) P_{g} R_{t^{*}}^{*} \hat{S}_{g^{*}}^{*}-R_{t} R_{t K} R_{t^{*} K^{*}}^{*} P_{g^{*}}^{*} \hat{S}_{g}\right]}{\bar{E}_{r} \bar{E}_{r^{*}}^{*} P_{g} P_{g^{*}}^{*}\left[\left(H R_{t t}-R_{t K}^{2}\right)\left(H R_{t^{*} t^{*}}^{*}-R_{t^{*} K^{*}}^{* 2}\right)-R_{t K}^{2} R_{t^{*} K^{*}}^{* 2}\right]},
\end{gathered}
$$

where the denominator of equations (26) and (27) is positive, and $\hat{S}_{g}=\bar{E}_{r}-P_{g}$ and $\hat{S}_{g^{*}}^{*}=\bar{E}_{r^{*}}^{*}-P_{g^{*}}^{*}$. It is important to note that the cooperative pollution taxes $\left(t^{c}\right)$ and $\left(t^{* c}\right)$ are independent of $\left(k^{f}\right)$. Intuitively, payments to foreign capital operating in the home country constitute a direct income transfer from the home to the foreign country. Therefore, the income loss of the home country exactly outweighs the income benefit of the foreign country, and as such it does not affect the maximization of their joint welfare.

In the present context of simultaneous cooperative choice of lump-sum (i.e., $\hat{S}_{g}=$ $\left.\hat{S}_{g^{*}}^{*}=0\right)$ and pollution taxes, equations $(26)$ and $(27)$ reduce to $t^{c}=P_{g}$ and $t^{* c}=P_{g^{*}}^{*}{ }^{19}$ In this case the cooperative optimal policies require that $t^{c}=P_{g}=\bar{E}_{r}{ }^{20}$ However, if lump-sum taxes were not chosen cooperatively it is possible that $t^{c} \gtrless P_{g}$ and/or $t^{* c} \gtrless P_{g^{*}}^{*}$. For example, if each country chooses the level of its lump-sum taxes non-cooperatively in order to maximize its own welfare, then while the level of public pollution abatement in each country is locally optimally provided, from the region's point of view, due to the cross-border pollution externality, there is global under-provision in both countries $\left(\hat{S}_{g}=\Theta^{*} E_{r^{*}}^{*}>0\right.$, and $\left.\hat{S}_{g}^{*}=\Theta E_{r}>0\right)$. In this case, $t^{c}>P_{g}$ and $t^{* c}>P_{g^{*}}^{*}$.

Proposition 2 Consider a two-country region with perfect capital mobility, and crossborder pollution between them. Part of pollution abatement is carried out by the public sector financed by means of lump-sum and pollution taxes. The first-best policy choice, maximizing the countries' joint welfare, entails their cooperation in choosing both their respective lump-sum and pollution taxes and requires that $t^{c}=P_{g}=\bar{E}_{r}$ and $t^{* c}=P_{g^{*}}^{*}=$ $\bar{E}_{r^{*}}^{*}$.

Note that cross-border pollution, not regional capital mobility, is the feature of the model mandating that the two countries choose cooperatively both lump-sum and pol-

\footnotetext{
${ }^{19}$ When both policies are chosen cooperatively a small increase in pollution tax in one country reduces net pollution in both countries (equations (13) and (14)).

${ }^{20}$ Hatzipanayotou, Lahiri, and Michael (2002b) find the same result but in their case this result applies to Nash taxes and not cooperative taxes.
} 
lution taxes in attaining the first-best policy choice. In the absence of cross-border pollution, the cooperative choice of pollution taxes alone suffices for attaining the first-best policy choice.

\subsection{Nash Equilibrium Lump-sum and Pollution Taxes}

We now derive the optimal Nash lump-sum and pollution taxes for the home and foreign countries and compare them to the benchmark cooperative case. The two countries choose these taxes simultaneously. In this non-cooperative game the only interactions between the two countries relevant to the analysis are those emanating from cross-border pollution and regional capital mobility.

\subsubsection{Nash Lump-sum Taxes}

Setting equations (16) and (17) equal to zero, we derive the Nash lump-sum taxes. The emerging equilibrium conditions require that Nash lump-sum taxes are chosen such that for the home country $E_{r}=P_{g}$ and for the foreign country such that $E_{r^{*}}^{*}=P_{g^{*}}^{*}$. These conditions constitute a dominant strategy for each country. That is, each country's choice of lump-sum taxes is independent of the other country's policy choice.

Comparing the Nash optimality conditions to those of the benchmark cooperative case we derive the following Proposition.

Proposition 3 Under the conditions of the model, Nash lump-sum tax levels are lower than the corresponding cooperative levels.

Proof. Consider the case of the home country. Since $P_{g}$ is constant and the same in both regimes, from equations (24), (25), and the discussion above it must hold that $E_{r}^{N}=E_{r}^{C}+\Theta^{*} E_{r}^{* C} \cdot{ }^{21}$ This implies that $E_{r}^{N}>E_{r}^{C}$. Given that the expenditure function is assumed strictly convex in $(r)$, we get that $r^{N}>r^{C}$. As shown by the comparative statics in the Appendix, an increase in $(T)$ does not affect the level of gross pollution (z), therefore $r^{N}>r^{C}$ implies that $g^{N}<g^{C}$. As a result we get that $T^{N}<T^{C}$. Similar reasoning yields $T^{* N}<T^{* C}$ for the foreign country.

Intuitively, the individual governments in setting their lump-sum taxes, do not account for the fact that because of cross-border pollution (i.e., a negative externality), the other

\footnotetext{
${ }^{21}$ The superscripts $(N)$ and $(C)$ denote the variables evaluated at the Nash and the cooperative equilibrium, respectively.
} 
country incurs a cost from pollution generated in the first country. Therefore, individual governments by not internalizing this externality set their Nash lump-sum taxes too low. In contrast, in the cooperative case the two countries accounting for this externality apply the relevant Samuelson rule for the regional optimal provision of the public pollution abatement.

\subsubsection{Nash Pollution Taxes}

Setting $(d u / d t)=0$ and $\left(d u^{*} / d t^{*}\right)=0$ in equations (18) and (20), we derive the following reaction functions:

$$
\begin{gathered}
t=P_{g}+\frac{-S_{g} H R_{t} P_{g^{*}}^{*}+\Theta R_{t K} R_{t^{*} K^{*}}^{*} P_{g} E_{r}\left(P_{g^{*}}^{*}-t^{*}\right)-k^{f} R_{t K} R_{K^{*} K^{*}}^{*} P_{g} P_{g^{*}}^{*}}{E_{r} P_{g^{*}}^{*}\left(H R_{t t}-R_{t K}^{2}\right)} \\
t^{*}=P_{g^{*}}^{*}+\frac{-S_{g^{*}}^{*} H R_{t^{*}}^{*} P_{g}+\Theta^{*} R_{t K} R_{t^{*} K^{*}}^{*} P_{g^{*}}^{*} E_{r^{*}}^{*}\left(P_{g}-t\right)+k^{f} R_{t^{*} K^{*}}^{*} R_{K K} P_{g} P_{g^{*}}^{*}}{E_{r^{*}}^{*} P_{g}\left(H R_{t^{*} t^{*}}^{*}-R_{t^{*} K^{*}}^{* 2}\right)} .
\end{gathered}
$$

Given that the structure of the game is such that lump-sum taxes are locally optimally chosen (i.e., $S_{g}=S_{g^{*}}^{*}=0$ ), solving simultaneously equations (28) and (29) gives the following expressions for each country's Nash pollution taxes. ${ }^{22}$

$$
\begin{aligned}
& t^{N}=P_{g}-k^{f} R_{t K} P_{g}^{2} P_{g^{*}}^{*}\left[E_{r^{*}}^{*} R_{K^{*} K^{*}}^{*}\left(H R_{t^{*} t^{*}}^{*}-R_{t^{*} K^{*}}^{* 2}\right)+\Theta R_{K K} R_{t^{*} K^{*}}^{* 2} E_{r}\right] / \Delta^{N} \\
& t^{* N}=P_{g}^{*}+k^{f} R_{t^{*} K^{*}}^{*} P_{g^{*}}^{* 2} P_{g}\left[E_{r} R_{K K}\left(H R_{t t}-R_{t K}^{2}\right)+\Theta^{*} R_{K^{*} K^{*}}^{*} R_{t K}^{2} E_{r^{*}}^{*}\right] / \Delta^{N},
\end{aligned}
$$

where $\Delta^{N}=E_{r} E_{r^{*}}^{*} P_{g} P_{g^{*}}^{*}\left[\left(H R_{t t}-R_{t K}^{2}\right)\left(H R_{t^{*} t^{*}}^{*}-R_{t^{*} K^{*}}^{* 2}\right)-\Theta \Theta^{*} R_{t K}^{2} R_{t^{*} K^{*}}^{* 2}\right]$ and is positive. From equations (30) and (31) we note that when lump-sum taxes are locally optimally chosen, the effect of pollution taxes on payments to foreign capital operating in the home country constitute the only difference between the Nash and cooperative tax rates.

Observing the above expressions we note that in general the Nash pollution taxes can be greater or smaller than the unit cost of the public pollution abatement, as opposed to the benchmark case of cooperative choice of both instruments. We resolve some of this ambiguity by stating the following Proposition, which considers some special cases.

Proposition 4 Under the conditions of the model

1. if $\Theta=0$, then $t^{N}>t^{c}=P_{g}$.

\footnotetext{
${ }^{22}$ The general expressions for the Nash pollution taxes when lump-sum taxes are not chosen optimally are given in the Appendix.
} 
2. If $\Theta^{*}=0$, then $t^{* N}<t^{* c}=P_{g^{*}}^{*}$.

3. If the two countries are symmetric in the sense that $E_{r}=E_{r^{*}}^{*}$ and $R_{K K}=R_{K^{*} K^{*}}^{*}$, then $t^{N}>t^{c}$ and $t^{* N}<t^{* c}$.

4. If countries are identical, then $k^{f}=0$ and $t^{N}=t^{c}=P_{g}, t^{* N}=t^{* c}=P_{g^{*}}^{*}$.

The proof of Proposition (4) follows from equations (30) and (31). Intuitively, the first two cases of Proposition (4) are directly derived from the assumption that home is the capital-importing and foreign is the capital-exporting country, and from the assumption that pollution is a capital intensive good in both countries. That is, the inflow of capital in the home country raises pollution, thus leading to a higher domestic Nash pollution tax level. The reverse holds for the foreign capital-exporting country. The intuition of the third case is as follows. Payments to foreign capital operating in the home country reduce real income, and thus lower the domestic households' marginal willingness to pay for pollution abatement (i.e., $E_{r u}>0$ ). As a result, at a constant pollution tax $(t)$, net pollution generated at home (i.e., $z-g$ ) rises. At the same time, the opposite holds in the foreign country, i.e., $z^{*}-g^{*}$ falls. If the two countries are symmetric, and since $\Theta \leq 1$ and $\Theta^{*} \leq 1$, then net pollution $\left(r=z-g+\Theta\left(z^{*}-g^{*}\right)\right)$ in the home country rises, and net pollution $\left(r^{*}=z^{*}-g^{*}+\Theta^{*}(z-g)\right)$ in the foreign country falls. Therefore, we get that in the home country $t^{N}>t^{c}$, and in the foreign country $t^{* N}<t^{* c}$. Finally, in the last case where the two countries are identical (i.e. $k^{f}=0$ ) there are no payments to foreign capital operating at home, and thus the cooperative and Nash pollution tax levels are the same. It is important, however, to note that if the two countries are identical and cooperate only in choosing their pollution taxes, while lump-sum taxes are chosen non-cooperatively (Nash taxes), then $t^{c}>t^{N}=P_{g}$ and $t^{* c}>t^{* N}=P_{g^{*}}^{*}$.

One of the key features of our model is that contrary to most of the literature we allow countries to be non-identical. We next examine how differences between the two countries affect optimal taxes. To do so consider first the case where the two countries are identical. If countries are identical, the return on capital is identical and $k^{f}=0$. In that case, if both taxes are chosen optimally $t^{N}=t^{c}=P_{g}$ and $t^{* N}=t^{* c}=P_{g^{*}}^{*}$ and from Proposition 3, $T^{N}<T^{c}$ and $T^{* N}<T^{* c}$. Therefore, if countries are identical and both taxes are chosen optimally there is no need for cooperation in pollution taxes since Nash taxes are efficient. However, there is scope for cooperation in lump sum taxes. If, on the other hand, the two countries are non-identical and choose both taxes optimally, 
Nash pollution taxes are not efficient. From Proposition 3 we still get that $T^{N}<T^{c}$ and $T^{* N}<T^{* c}$. Proposition 4 summarizes the sufficient conditions for $t^{N}>t^{c}$ and $t^{* N}<t^{* c}$.

\section{Capital Mobility and the Effect of Pollution Taxes on net Pollution}

In what follows we examine how, ceteris paribus, regional capital mobility alters the effectiveness of pollution taxes in reducing net pollution. The analysis utilizes different initial conditions according to whether or not the two countries act cooperatively in choosing optimally their policy instruments (i.e., lump-sum and/or pollution taxes). Namely, we examine how capital mobility affects the impact of an increase in pollution taxes on net pollution (i.e., $d r / d t$ ) in each of the two cases in Section 4 , that is, when (i) the two countries choose their policies cooperatively and (ii) both countries choose their policies non-cooperatively (Nash). This in itself is another analytical novelty of the present paper. That is, while some of the previously reviewed studies examine the effects of capital mobility on pollution levels, to the best of our knowledge, none of them examines the impact of capital mobility on the effectiveness of the optimally chosen environmental policy instruments in reducing net pollution. ${ }^{23}$

Consider the case of no regional capital mobility. Then, in both cases, when lumpsum taxes are optimally chosen, cooperatively in the cooperative case (i.e., $\hat{S}_{g}=\hat{S}_{g^{*}}^{*}=0$ ) and non-cooperatively in the Nash case (i.e., $S_{g}=S_{g^{*}}^{*}=0$ ), the optimal pollution tax equals the unit price of the public pollution abatement in both countries. This is easily observed from equations (26) and (27) in the case of the cooperative equilibrium, and from equations (30) and (31) in the case of non-cooperative Nash equilibrium. Moreover, equation (13), and its counterpart for the foreign country (i.e., $d r^{*} / d t^{*}$ ) indicate that raising the pollution tax, unambiguously reduces local net pollution. ${ }^{24}$ Note that the first two right-hand-side terms in the reduced form of equation (13), are due to regional capital mobility.

Assuming the existence of regional capital mobility, we first consider the case where the two countries choose cooperatively both their lump-sum and pollution taxes in order

\footnotetext{
${ }^{23}$ Damania (2000) defines the effectiveness of environmental policy in the same way but looks at the impact of environmental policy on the financial structure of firms.

${ }^{24}$ It is easily shown that when lump-sum taxes are optimally chosen, and in the absence of regional capital mobility, $(d r / d t)=-\Delta^{-1} P_{g^{*}}^{*} R_{t}<0$, and similarly, $(d r / d t)=-\Delta^{-1} P_{g} R_{t^{*}}^{*}<0$.
} 
to maximize their joint welfare. In this case, the cooperative pollution taxes equal the prices of public pollution abatement in each country and thus the effect of pollution taxes on net pollution is not affected by the presence of capital mobility when evaluated at the cooperative equilibrium. If, however, the two countries cooperate in their choice of pollution taxes but choose lump-sum taxes non-cooperatively, so as to each maximize its own welfare, then the effect of capital mobility is ambiguous. For zero or small $\Theta$, capital mobility reduces the effectiveness of the increase in pollution taxes on net pollution. ${ }^{25}$ Similarly, for small $\Theta^{*}$, the presence of capital mobility increases $d r^{*} / d t^{*}$.

Next, we examine how capital mobility affects the impact of an increase in the home pollution tax on its net pollution evaluated at Nash equilibrium. The following Proposition summarizes the results:

Proposition 5 Within the assumptions of the model, the presence of capital mobility decreases (increases) the effectiveness of an increase in the pollution tax on net pollution evaluated at $\mathrm{Nash}^{26}$ for the capital importing (exporting) country if i) $\Theta=0\left(\Theta^{*}=0\right)$ and $\Theta^{*} \geq 0(\Theta \geq 0)$ and ii) when $\Theta>0$ and $\Theta^{*}>0$ and both countries are symmetric in the sense that $E_{r}=E_{r^{*}}^{*}$ and $R_{K K}=R_{K^{*} K^{*}}^{*}$.

Intuitively, when $\Theta=0$ the residents of the home country are only affected by changes in, $z-g$. Capital mobility affects both $z$ and $g$. The increase in $t$ leads to an outflow of capital from the home to the foreign country, which in turn lowers $z$. On the other hand the effect on $g$ is negative since the capital outflow reduces pollution and thus pollution tax revenue. At Nash $t^{N}>P_{g}$ and thus the effect on $g$ is smaller than that on $z$, and thus $z-g$ is reduced. In the presence of transboundary pollution (i.e. $\Theta>0$ and $\Theta^{*}>0$ ) the same result holds if the two countries are symmetric. The intuition is the same as that following Proposition (4). It is important to note that if the two countries are identical the presence of capital mobility does not affect the impact of the pollution tax on net pollution.

\footnotetext{
${ }^{25}$ In other words it increases $d r / d t$. The more negative $d r / d t$ is the more effective $t$ is in reducing net pollution.

${ }^{26}$ Nash equilibrium refers to the case where the two countries apply their Nash lump-sum taxes and their Nash pollution taxes simultaneously.
} 


\section{Conclusion}

One of the most important concerns over the process of globalization is its impact on the environment. Environmentalists fear, among other things, that increased international capital mobility will lead to a deterioration of the global environment since in an effort to attract capital, countries will engage in a "race to the bottom" in environmental standards. Since pollution is not confined within national borders, this will lead to the deterioration of the neighboring countries environment. Triggered by such concerns a relatively new literature has addressed various aspects of the interaction between international capital mobility and the quality of the environment. The contribution of the paper to this emerging literature is twofold. First, following ample real world evidence, it allows for pollution abatement provided by the public sector in addition to abatement of pollution by the private sector. The paper also assumes, motivated by empirical evidence, that pollution tax revenue raised by the government is earmarked to finance its own abatement activity. Within this framework, we examine, among other things, the optimal cooperative and Nash taxes. Second, while the related studies have focused on the impact of capital mobility on national and global levels of pollution, we focus on the impact of capital mobility on the effectiveness of pollution taxes in reducing net pollution, as well.

To address these issues, the paper presents a model of a region with two non-identical countries with cross border pollution, free trade in goods and perfect capital mobility within the region. Pollution, a by-product of production adversely affects welfare and is abated by the private and public sectors in both countries. The government uses revenue collected from pollution and lump-sum taxes to finance public pollution abatement. This framework enables us to relate the optimal pollution tax policies with the marginal cost of public pollution abatement.

We show, among other things, that the first-best policy is achieved when both countries choose both tax instruments cooperatively and requires that the optimal pollution tax in each country is equal to the unit cost of public pollution abatement and to the global damage caused by a unit of pollution generated by that country. In this case, the presence of regional capital mobility has no impact on the effectiveness of pollution taxes in reducing net pollution. If, however, each country chooses only the pollution taxes cooperatively, while lump-sum taxes are chosen non-cooperatively (i.e., to maximize its 
own welfare), then from the regions' perspective, due to cross-border pollution, there is under-provision of public pollution abatement, and the cooperative pollution tax is greater than the unit cost of public pollution abatement. In this case, the presence of capital mobility reduces the effectiveness of the pollution tax on net pollution for each country when cross-border pollution is small. When each country acts non-cooperatively, in order to maximize its own welfare, then i) the non-cooperative lump-sum taxes are lower than the cooperative ones, and ii) the Nash pollution tax is expected to be greater (smaller) than its cooperative level for the capital importing (exporting) country.

If the two countries are identical, then i) in the Nash equilibrium, the Nash pollution tax is equal to the cooperative one and ii) capital mobility has no impact on the effectiveness of pollution taxes on net pollution. 


\section{Appendix}

$$
\left[\begin{array}{ccccc}
1 & 0 & -E_{r} & -\Theta E_{r} & -E_{r}\left(R_{t K}-\Theta R_{t^{*} K^{*}}^{*}\right)+k^{f} R_{K K} \\
0 & 1 & -\Theta^{*} E_{r^{*}}^{*} & -E_{r^{*}}^{*} & E_{r^{*}}^{*}\left(R_{t^{*} K^{*}}^{*}-\Theta^{*} R_{t K}\right)-k^{f} R_{K K} \\
0 & 0 & P_{g} & 0 & t R_{t K} \\
0 & 0 & 0 & P_{g^{*}}^{*} & -t^{*} R_{t^{*} K^{*}}^{*} \\
0 & 0 & 0 & 0 & H
\end{array}\right]\left[\begin{array}{c}
d u \\
d u^{*} \\
d g \\
d g^{*} \\
d K
\end{array}\right]=
$$

$$
\begin{gathered}
{\left[\begin{array}{c}
E_{r} R_{t t}+R_{t}-k^{f} R_{t K} \\
\Theta^{*} E_{r^{*}}^{*} R_{t t}+k^{f} R_{t K} \\
-R_{t}-t R_{t t} \\
0 \\
-R_{t K}
\end{array}\right] d t+\left[\begin{array}{c}
\Theta E_{r} R_{t^{*} t^{*}}^{*} \\
E_{r^{*}}^{*} R_{t^{*} t^{*}}^{*}+R_{t^{*}}^{*} \\
0 \\
-R_{t^{*}}^{*}-t^{*} R_{t^{*} t^{*}}^{*} \\
-R_{t^{*} K^{*}}^{*}
\end{array}\right] d t^{*}} \\
+\left[\begin{array}{c}
-1 \\
0 \\
1 \\
0 \\
0
\end{array}\right] d T+\left[\begin{array}{c}
0 \\
-1 \\
0 \\
1 \\
0
\end{array}\right] d T^{*}
\end{gathered}
$$

\begin{tabular}{|c|c|c|}
\hline \multicolumn{3}{|c|}{$t_{N}=P_{g}+\left\{E_{r^{*}}^{*} P_{g}\left(H R_{t^{*} t^{*}}^{*}-R_{t^{*} K^{*}}^{* 2}\right)\left(-S_{g} H R_{t} P_{g^{*}}^{*}-k^{f} R_{t K} R_{K^{*} K^{*}}^{*} P_{g} P_{g^{*}}^{*}\right)\right.$} \\
\hline \multicolumn{3}{|c|}{$\left.-\Theta R_{t K} R_{t^{*} K^{*}}^{*} P_{g} E_{r}\left(-S_{g^{*}}^{*} H R_{t^{*}}^{*} P_{g}+k^{f} R_{K K} R_{t^{*} K^{*}}^{*} P_{g} P_{g^{*}}^{*}\right)\right\} / \Delta_{N}$} \\
\hline \multicolumn{3}{|c|}{$t_{N}^{*}=P_{g^{*}}^{*}+\left\{E_{r} P_{g^{*}}^{*}\left(H R_{t t}-R_{t K}^{2}\right)\left(-S_{g^{*}}^{*} H R_{t^{*}}^{*} P_{g}+k^{f} R_{t^{*} K^{*}}^{*} R_{K K} P_{g} P_{g^{*}}^{*}\right)\right.$} \\
\hline \multicolumn{3}{|c|}{$\left.-\Theta^{*} R_{t K} R_{t^{*} K^{*}}^{*} P_{g^{*}}^{*} E_{r^{*}}^{*}\left(-S_{g} H R_{t} P_{g^{*}}^{*}-k^{f} R_{K^{*} K^{*}}^{*} R_{t K} P_{g} P_{g^{*}}^{*}\right)\right\} / \Delta_{N}$} \\
\hline \multirow{2}{*}{\multicolumn{3}{|c|}{$\begin{array}{l}\frac{\Delta r}{d t^{*}}=-P_{g^{*}}^{*} R_{t K} R_{t^{*} K^{*}}^{*}\left(P_{g}-t\right)-\Theta P_{g}\left(H R_{t^{*} t^{*}}^{*}-R_{t^{*} K^{*}}^{* 2}\right)\left(P_{g^{*}}^{*}-t^{*}\right)+\Theta H P_{g} R_{t^{*}}^{*} \\
\Delta \frac{d r^{*}}{d t^{*}}=-P_{g}\left(H R_{t^{*} t^{*}}^{*}-R_{t^{*} K^{*}}^{* 2}\right)\left(P_{g^{*}}^{*}-t^{*}\right)-\Theta^{*} R_{t K} R_{t^{*} K^{*}}^{*} P_{g^{*}}^{*}\left(P_{g}-t\right)+H P_{g} R_{t^{*}}^{*}\end{array}$}} \\
\hline & & \\
\hline$\frac{d u}{d \Theta}=-E_{r}\left(-R_{t^{*}}^{*}-g^{*}\right)$ & $\frac{d K}{d \Theta^{*}}=0$ & $\frac{d g^{*}}{d \Theta}=0$ \\
\hline$\frac{d u}{d \Theta^{*}}=0$ & $\Delta \frac{d g}{d t^{*}}=-P_{g^{*}}^{*} t R_{t K} R_{t^{*} K^{*}}^{*}$ & $\frac{d g^{*}}{d \Theta^{*}}=0$ \\
\hline$\frac{d u^{*}}{d \Theta}=0$ & $\Delta \frac{d g}{d T}=H P_{g^{*}}^{*}$ & $\frac{d r}{d T}=\frac{-1}{P_{g}}$ \\
\hline$\frac{d u^{*}}{d \Theta^{*}}=-E_{r^{*}}^{*}\left(-R_{t}-g\right)$ & $\frac{d g}{d T^{*}}=0$ & $\frac{d r}{d T^{*}}=\frac{-\Theta}{P_{g^{*}}^{*}}$ \\
\hline$\frac{d K}{d t}=\frac{-R_{t K}}{H}$ & $\frac{d g}{d \Theta}=0$ & $\frac{d r}{d \Theta}=-R_{t^{*}}^{*}-g^{*}$ \\
\hline$\frac{d K}{d t^{*}}=\frac{R_{t^{*} K^{*}}^{*}}{H}$ & $\frac{d g}{d \Theta^{*}}=0$ & $\frac{d r}{d \Theta^{*}}=0$ \\
\hline$\frac{d K}{d T}=0$ & $\Delta \frac{d g^{*}}{d t^{*}}=P_{g} t^{*} R_{t^{*} K^{*}}^{* 2}-H P_{g}\left(R_{t^{*}}^{*}+t^{*} R_{t^{*} t^{*}}^{*}\right)$ & $\frac{d r^{*}}{d T}=\frac{-\Theta^{*}}{P_{g}}$ \\
\hline$\frac{d K}{d T^{*}}=0$ & $\Delta \frac{d g^{*}}{d T}=0$ & $\frac{d r^{*}}{d T^{*}}=\frac{-1}{P_{g^{*}}^{*}}$ \\
\hline$\frac{d K}{d \Theta}=0$ & $\Delta \frac{d g^{*}}{d T^{*}}=H P_{g}$ & $\frac{d r^{*}}{d \Theta}=0$ \\
\hline
\end{tabular}




\section{References}

Antweiler, W., B. R. Copeland, and M. S. Taylor (2001): "Is Free Trade Good for the Environment?," American Economic Review, 91(4), 877-908.

Brett, C., And M. Keen (2000): "Political Uncertainty and the Earmarking of Environmental Taxes," Journal of Public Economics, 75(3), 315-340.

Chao, C.-C., And E. S. H. Yu (1998): "Optimal Pollution and Foreign-Investment Taxes in a Small Open Economy," Journal of International Trade and Economic Development, 7(1), 171-185.

(1999): "Foreign Aid, the Environment, and Welfare," Journal of Development Economics, 59(2), 553-564.

(2000): "TRIMs, Environmental Taxes, and Foreign Investment," Canadian Journal of Economics, 33(3), 799-817.

Copeland, B. R. (1994): "International Trade and the Environment: Policy Reform in a Polluted Small Open Economy," Journal of Environmental Economics and Management, 26(1), 44-65.

(1996): "Pollution Content Tariffs, Environmental Rent Shifting, and the Control of Cross-Border Pollution," Journal of International Economics, 40(3-4), 459-76.

Copeland, B. R., and M. S. Taylor (1995): "Trade and Transboundary Pollution," American Economic Review, 85(4), 716-37.

(1997): "A Simple Model of Trade, Capital Mobility and the Environment," NBER Working Paper, 5898.

Damania, R. (2000): "Financial Structure and the Effectiveness of Pollution Control in an Oligopolistic Industry," Resource and Energy Economics, 22(1), 21-36.

Gray, W. B. (1997): "Manufacturing Plant Location: Does State Pollution Regulation Matter?," NBER Working Paper, 5880.

Grossman, G. M., and A. B. Krueger (1993): "Environmental Impacts of a North American Free Trade Agreement," in The Mexico-U.S. Free Trade Agreement, ed. by P. M. Garber, pp. 13-56. MIT Press, Cambridge and London.

Hatzipanayotou, P., S. Lahiri, and M. S. Michael (2002a): "Can Cross-Border Pollution Reduce Pollution?," Canadian Journal of Economics, 35(4). 
Hatzipanayotou, P., S. Lahiri, and M. S. Michael (2002b): "Reforms of Environmental Policies in the Presence of Cross-Border Pollution and Public-Private CleanUp," CESifo Working Paper, 638(8).

Hoel, M., and P. Shapiro (2001): "Population Mobility and Transboundary Environmental Problems," CESifo Working Papers Series, 488.

Jaffe, A. B., S. R. Peterson, P. R. Portney, and R. N. Stanvis (1995): "Environmental Regulation and the Competitiveness of U.S. Manufacturing: What Does the Evidence Tell Us?," Journal of Economic Literature, 33(1), 132-163.

Ludema, R. D., and I. Wooton (1997): "International Trade Rules and Environmental Cooperation under Asymmetric Information," International Economic Review, 38(3), 605-25.

Markusen, J. R. (1975): "Cooperative Control of International Pollution and Common Property Resources," Quarterly Journal of Economics, 89(4), 618-32.

Markusen, J. R., E. R. Morey, and N. D. Olewiler (1993): "Environmental Policy When Market Structure and Plant Locations Are Endogenous," Journal of Environmental Economics and Management, 24(1), 69-86.

Merrifield, J. D. (1988): "The Impact of Selected Abatement Strategies on Transnational Pollution, the Terms of Trade, and Factor Rewards: A General Equilibrium Approach," Journal of Environmental Economics and Management, 15(3), 259-84.

Rauscher, M. (1991): "National Environmental Policies and the Effects of Economic Integration," European Journal of Political Economy, 7, 313-329.

- (1997): International Trade, Factor Movements, and the Environment. Clarendon Press, Oxford and New York.

Silva, E. C. D., and A. J. Caplan (1997): "Transboundary Pollution Control in Federal Systems," Journal of Environmental Economics and Management, 34(2), 17386.

Tobey, J. A. (1990): "The Effects of Domestic Environmental Policies on Patterns of World Trade: An Empirical Test," Kyklos, 43(2), 191-209.

Turunen-Red, A., And A. D. Woodland (1998): "Multilateral Reforms on Trade and Environmental Policy," Discussion Paper, Department of Economics, University of Sydney. 


\section{CESifo Working Paper Series}

(for full list see www.cesifo.de)

756 Jan K. Brueckner, Internalization of Airport Congestion: A Network Analysis, July 2002

757 Lawrence M. Kahn, The Impact of Wage-Setting Institutions on the Incidence of Public Employment in the OECD: 1960-98, July 2002

758 Sijbren Cnossen, Tax Policy in the European Union, August 2002

759 Chandima Mendis, External Shocks and Banking Crises in Developing Countries: Does the Exchange Rate Regime Matter?, August 2002

760 Bruno S. Frey and Lars P. Feld, Deterrence and Morale in Taxation: An Empirical Analysis, August 2002

761 Lars Calmfors and Åsa Johansson, Nominal Wage Flexibility, Wage Indexation and Monetary Union, August 2002

762 Alexander R. W. Robson and Stergios Skaperdas, Costly Enforcement of Property Rights and the Coase Theorem, August 2002

763 Horst Raff, Preferential Trade Agreements and Tax Competition for Foreign Direct Investment, August 2002

764 Alex Cukierman and V. Anton Muscatelli, Do Central Banks have Precautionary Demands for Expansions and for Price Stability? - Theory and Evidence, August 2002

765 Giovanni Peri, Knowledge Flows and Knowledge Externalities, August 2002

766 Daniel Friedman and Nirvikar Singh, Equilibrium Vengeance, August 2002

767 Sam Bucovetsky and Michael Smart, The Efficiency Consequences of Local Revenue Equalization: Tax Competition and Tax Distortions, August 2002

768 Tapio Palokangas, International Labour Market Regulation and Economic Growth with Creative Destruction, August 2002

769 Rudi Dornbusch, The New International Architecture, September 2002

770 Hans-Werner Sinn, Weber's Law and the Biological Evolution of Risk Preferences: The Selective Dominance of the Logarithmic Utility Function, September 2002

771 Thomas Mayer, The Macroeconomic Loss Function: A Critical Note, September 2002

772 Seppo Honkapohja and Kaushik Mitra, Learning Stability in Economies with Heterogenous Agents, September 2002 
773 David Laidler, Inflation Targets Versus International Monetary Integration - A Canadian Perspective, September 2002

774 Morten I. Lau, Panu Poutvaara, and Andreas Wagener, The Dynamic Cost of the Draft, September 2002

775 Steven Brakman, Harry Garretsen, and Charles van Marrewijk, Locational Competition and Agglomeration: The Role of Government Spending, September 2002

776 Anke S. Kessler and Christoph Lülfesmann, The Theory of Human Capital Revisited: On the Interaction of General and Specific Investments, September 2002

777 Kjell Erik Lommerud, Frode Meland and Lars Sørgard, Unionized Oligopoly, Trade Liberalization and Location Choice, September 2002

778 Antonio Merlo and François Ortalo-Magné, Bargaining over Residential Real Estate: Evidence from England, September 2002

779 Yu-Fu Chen and Michael Funke, Exchange Rate Uncertainty and Labour Market Adjustment under Fixed and Flexible Exchange Rates, September 2002

780 Michael S. Michael, International Migration, Income Taxes and Transfers: A Welfare Analysis, September 2002

781 Clemens Fuest and Alfons Weichenrieder, Tax Competition and Profit Shifting: On the Relationship between Personal and Corporate Tax Rates, October 2002

782 Jan Bouckaert and Hans Degryse, Softening Competition by Enhancing Entry: An Example from the Banking Industry, October 2002

783 Johann K. Brunner and Susanne Pech, Adverse Selection in the Annuity Market with Sequential and Simultaneous Insurance Demand, October 2002

784 Gregory D. Hess and Eduard Pelz, The Economic Welfare Cost of Conflict: An Empirical Assessment, October 2002

785 Jan Erik Askildsen, Uwe Jirjahn, and Stephen C. Smith, Works Councils and Environmental Investment: Theory and Evidence from German Panel Data, October 2002

786 Geir H. Bjønnes, Dagfinn Rime, and Haakon O. Aa. Solheim, Volume and Volatility in the FX-Market: Does it matter who you are?, October 2002

787 John Evans and John Fingleton, Entry Regulation and the Influence of an Incumbent Special Interest Group, October 2002

788 Wolfgang Ochel, International Comparisons and Transfer of Labour Market Institutions, October 2002

789 B. Gabriela Mundaca, Moral Hazard Effects of Bailing out under Asymmetric Information, October 2002 
790 Gene M. Grossman and Edwin L.-C. Lai, International Protection of Intellectual Property, October 2002

791 John Hassler, José V. Rodriguez Mora, Kjetil Storesletten, and Fabrizio Zilibotti, A Positive Theory of Geographic Mobility and Social Insurance, October 2002

792 Paul De Grauwe and Marianna Grimaldi, The Exchange Rate in a Model with Heterogeneous Agents and Transactions Costs, October 2002

793 Guido Friebel and Mariassunta Giannetti, Fighting for Talent: Risk-shifting, Corporate Volatility, and Organizational Change, October 2002

794 Jan Erik Askildsen, Badi H. Baltagi, and Tor Helge Holmås, Will Increased Wages Reduce Shortage of Nurses? A Panel Data Analysis of Nurses' Labour Supply, October 2002

795 Marko Köthenbürger and Panu Poutvaara, Social Security Reform and Intergenerational Trade: Is there Scope for a Pareto-Improvement?, October 2002

796 Paul De Grauwe and Laura Rinaldi, A Model of the Card Payment System and the Interchange Fee, October 2002

797 Volker Böhm and Tomoo Kikuchi, Dynamics of Endogenous Business Cycles and Exchange Rate Volatility, October 2002

798 Mariam Camarero, Javier Ordóñez, and Cecilio Tamarit, The Euro-Dollar Exchange Rate: Is it Fundamental?, October 2002

799 Misa Tanaka, How Do Bank Capital and Capital Adequacy Regulation Affect the Monetary Transmission Mechanism?, October 2002

800 Jörg Baten and Andrea Wagner, Autarchy, Market Disintegration, and Health: The Mortality and Nutritional Crisis in Nazi Germany, 1933-1937, October 2002

801 Saku Aura, Uncommitted Couples: Some Efficiency and Policy Implications of Marital Bargaining, October 2002

802 Wolfram F. Richter, Delaying Integration of Immigrant Labor for the Purpose of Taxation, October 2002

803 Gil S. Epstein and Shmuel Nitzan, The Politics of Randomness, October 2002

804 John Hassler and José V. Rodriguez Mora, Should UI Benefits Really Fall over Time?, October 2002

805 Friedrich Breyer and Stefan Felder, The Dead-anyway Effect Revis(it)ed, October 2002

806 Assar Lindbeck and Solveig Wikström, E-exchange and the Boundary between Households and Organizations, November 2002 
807 Dieter Bös, Contests Among Bureaucrats, November 2002

808 Steven Brakman, Harry Garretsen, and Marc Schramm, The Strategic Bombing of German Cities during World War II and its Impact on City Growth, November 2002

809 Florian Englmaier and Achim Wambach, Contracts and Inequity Aversion, November 2002

810 Sarbajit Sengupta, Delegating Recruitment under Asymmetric Information, December 2002

811 Rajshri Jayaraman, On the Partial Public Provision of a Private Good, December 2002

812 Stéphanie Stolz, Banking Supervision in Integrated Financial Markets: Implications for the EU, December 2002

813 Christian Keuschnigg, Taxation of a Venture Capitalist with a Portfolio of Firms, December 2002

814 Inés Macho-Stadler and David Pérez-Castrillo, Settlement in Tax Evasion Prosecution, December 2002

815 Rainer Niemann and Dirk Simons, Costs, Benefits, and Tax-induced Distortions of Stock Option Plans, December 2002

816 Jan-Egbert Sturm and Barry Williams, Deregulation, Entry of Foreign Banks and Bank Efficiency in Australia, December 2002

817 V. Anton Muscatelli, Patrizio Tirelli, and Carmine Trecroci, Monetary and Fiscal Policy Interactions over the Cycle: Some Empirical Evidence, December 2002

818 Claude Hillinger, A General Theory of Price and Quantity Aggregation and Welfare Measurement, December 2002

819 Erkki Koskela and Ronnie Schöb, Optimal Capital Taxation in Economies with Unionised and Competitive Labour Markets, December 2002

820 Sheilagh Ogilvie, Guilds, Efficiency, and Social Capital: Evidence from German ProtoIndustry, December 2002

821 Hans Gersbach and Verena Liessem, Financing Democracy, December 2002

822 Costas Hadjiyiannis, Panos Hatzipanayotou, and Michael S. Michael, Optimal Tax Policies with Private-Public Clean-Up, Cross-Border Pollution and Capital Mobility, December 2002 